\title{
KLASIFIKASI GANGGUAN PADA SALURAN TRANSMISI MENGGUNAKAN JARINGAN SYARAF TIRUAN METODE KOHONEN
}

\author{
Denny Irawan
}

\author{
Program Studi Teknik Elektro Universitas Muhammadiyah Gresik
}

\begin{abstract}
Abstrak
Pengamanan saluran transmisi sangat penting untuk menjamin kontinyuitas pelayanan tenaga listrik. Gangguan pada saluran transmisi harus cepat dideteksi, diklasifikasikan dan ditentukan lokasinya dengan tepat. Dalam kerangka kerja ini, fokus terpenting adalah kecepatan dan ketepatan untuk menentukan klasifikasi gangguan.

Gangguan yang sering terjadi pada saluran transmisi adalah gangguan hubung singkat. Gangguan hubung singkat yang akan diklasifikasikan meliputi satu fasa ketanah, dua fasa ketanah, tiga fasa ketanah dan gangguan hubung singkat antar fasa yaitu fasa-fasa dan tiga fasa.

Ada banyak metode dalam penggunaan jaringan syaraf tiruan antara lain : Back Propagation, Radial Basic Function, Multilayer Perceptron dan sebagainya. Dalam penelitian ini akan mempresentasikan penggunaan jaringan syaraf tiruan metode Kohonen untuk pengklasifikasian gangguan pada saluran transmisi. Metode ini adalah suatu desain sistem yang mampu menyajikan secara cepat dan tepat perkiraan dan tipe dari kelas gangguan berdasarkan pengukuran tegangan dan arus tiga fasa pada saluran transmisi. Sistem yang digunakan adalah dengan pemrosesan sinyal arus dan tegangan tiga fasa yang disimulasikan dengan program komputer.
\end{abstract}

Kata Kunci : Saluran transmisi, jaringan syaraf tiruan.

\section{PENDAHULUAN}

Dengan semakin berkembangnya kebutuhan masyarakat akan adanya tenaga listrik, maka kontinyuitas pelayanan tenaga listrik menjadi hal yang sangat penting dan perlu untuk diperhatikan, sehingga perlindungan terhadap saluran transmisi mempunyai peranan penting dalam perlindungan sistem tenaga listrik, hal ini disebabkan karena saluran transmisi merupakan elemen penting suatu jalajala yang menghubungkan stasiun pembangkit dengan pusat-pusat beban.

Karena panjangnya jarak yang harus dirintangi oleh saluran transmisi, maka saluran transmisi merupakan sasaran utama dari sebagian besar gangguan yang terjadi dalam sistem daya. Salah satu gangguan yang sering terjadi adalah gangguan hubung singkat, baik gangguan hubung singkat antar fasa maupun gangguan hubung singkat fasa dengan tanah. Gangguan hubung singkat pada saluran transmisi apabila bersifat permanen pada umumnya dapat mengakibatkan kerusakan mekanis pada peralatan-peralatan listrik yang terhubung dengan sistem yang sedang mengalami gangguan hubung singkat tersebut.

Agar tidak berpengaruh terhadap peralatan-peralatan lain, maka secepatnya gangguan hubung singkat ini perlu untuk dideteksi, diklasifikasikan dan ditentukan lokasinya dengan tepat dan jelas secepat mungkin. Dalam sistem daya yang modern, penentuan jenis gangguan hubung singkat yang terjadi dengan cepat tentu akan sangat membantu dalam penanganan gangguan.

Salah satu cara untuk mengetahui dengan tepat dan cepat jenis gangguan hubung singkat yang terjadi adalah dengan menggunakan jaringan syaraf tiruan metode Kohonen. Pada metode ini yang akan diproses sebagai input adalah pola sinyal arus dan pola sinyal tegangan pada kondisi normal maupun pada saat gangguan.

Metodologi yang dipakai adalah pola pengenalan sinyal gangguan. Yang akan digunakan pada penelitian ini adalah pola sinyal arus yang meliputi sinyal arus fasa a, b dan c, pola sinyal tegangan fasa a, b dan c serta pola sinyal tegangan antar fasa, yaitu fasa ab, bc dan ca. Dari pola sinyal kemudian akan dicari nilai Power Spectral Density-nya (Power Spectrum), kemudian nilai dari Power Spectrum ini akan dinormalisasi sesuai dengan fungsi pemampat untuk kemudian akan diolah sebagai input oleh jaringan syaraf tiruan.

Diagram blok penyelesaiannya adalah : 


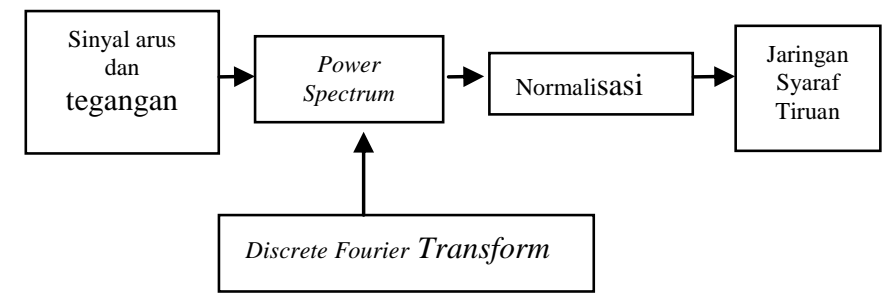

Gambar 1. Diagram Blok Penyelesaian

\section{KLASIFIKASI GANGGUAN}

\subsection{Gangguan Hubung Singkat}

Sistem dianalisa dalam keadaan peralihan dan simetri/tidak simetri. Atau analisa dilakukan sesaat ( $\mathrm{s} / \mathrm{d} \sim 1$ detik) setelah terjadi gangguan dalam sistem, dimana sistem mungkin dalam keadaan simetri atau tidak simetri.

Tujuan dari analisa hubung singkat adalah untuk menentukan arus dan tegangan maksimum dan minimum pada bagian-bagian atau titik-titik tertentu dari suatu sistem tenaga listrik untuk jenis-jenis gangguan yang terjadi, sehingga dapat ditentukan pengaman, rele dan pemutus tenaga (Circuit Breaker) untuk mengamankan sistem dari keadaan tidak normal dalam waktu seminimal mungkin.

\subsection{Jenis Gangguan}

Gangguan pada sistem tenaga listrik adalah suatu keadaan yang menyebabkan bekerjanya rele dan menjatuhkan (trip) pemutus tenaga (PMT), sehingga menyebabkan terputusnya aliran daya yang melalui PMT tersebut. Adapun gangguan tersebut terjadi disebabkan karena adanya kesalahan mekanis, termis dan tegangan lebih atau karena adanya material yang sudah cacat atau rusak.

Bila ditinjau dari segi lamanya waktu gangguan, maka dapat dikelompokkan menjadi :

a. Gangguan sementara.(temporary).

b. Gangguan permanen (stationary).

Untuk gangguan temporer yaitu apabila gangguan tersebut terjadi hanya dalam waktu yang singkat, kemudian sistem kembali normal yang ditandai dengan normalnya kerja dari pemutus tenaga setelah dimasukkan kembali. Penyebab gangguan dapat diakibatkan oleh petir, dimana terjadi loncatan bunga api listrik pada isolasi udara atau minyak.

Gangguan yang bersifat permanen adalah gangguan yang baru dapat dihilangkan setelah lokasi gangguan tersebut diisolir dengan bekerjanya pemutus tenaga. Penyebab gangguan bisa disebabkan adanya kerusakan pada peralatan sistemnya, sehingga gangguan baru bisa diatasi setelah kerusakan pada peralatan tersebut sudah diperbaiki. Sedangkan untuk gangguan temporer yang terjadi berulang-ulang akan dapat menyebabkan timbulnya kerusakan pada peralatan sistem dan hal ini dapat pula menimbulkan gangguan yang bersifat permanen sebagai akibat adanya kerusakan peralatan tersebut.

Ditinjau dari jenisnya maka gangguan yang mungkin terjadi ada sistem tenaga listrik 3 fasa :

A. Gangguan shunt (hubung singkat).

1. Hubung singkat 3 fasa (L-L-L).

2. Hubung singkat 3 fasa ke tanah (L-L-L-G).

3. Hubung singkat 1 fasa ke tanah (1L-G).

4. Hubung singkat antar fasa (L-L).

5. Hubung singkat antar fasa ke tanah (2L-G).

B. Gangguan seri (hubungan terbuka).

1. Satu saluran terbuka (1L-0).

2. Dua saluran terbuka (21-0).

3. Impedansi seri tak seimbang.

C. Gangguan simultan

1. Shunt-Shunt.

2. Shunt-Seri.

3. Seri-seri. 


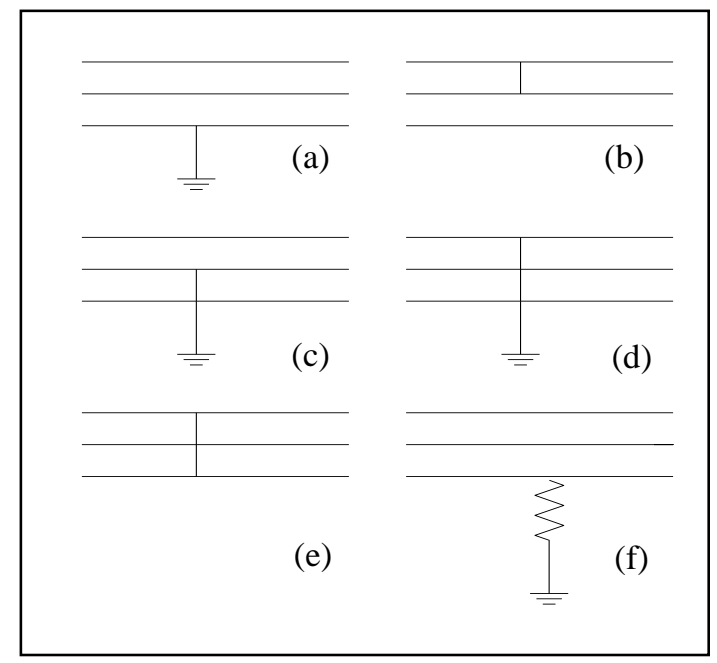

Gambar 2 Gangguan Shunt Yang Terjadi Pada Sistem Tenaga Listrik

Dari jenis gangguan tersebut dapat digolongkan menjadi dua kelompok gangguan :

a. Gangguan hubung singkat simetris.

b. Gangguan hubung singkat tidak simetris.

\section{JARINGAN SYARAF TIRUAN (JST)}

\subsection{Jaringan Syaraf Manusia}

Sistem syaraf manusia tidak mengacu pada otak manusia, tetapi juga meliputi sistem sensoris tubuh, yang menerima rangsangan atau informasi dari luar tubuh, dan sistem motoris yang berhubungan dengan pergerakan atau reaksi tubuh terhadap rangsangan tadi. Sistem syaraf manusia tidak mengacu pada otak manusia, tetapi juga meliputi sistem sensoris tubuh, yang menerima rangsangan atau informasi dari luar tubuh, dan sistem motoris yang berhubungan dengan pergerakan atau reaksi tubuh terhadap rangsangan tadi.

Sistem sensoris tubuh akan menjalankan informasi sensoris dari reseptor yang ada hampir di seluruh tubuh ke otak, yang kemudian diolah untuk menentukan reaksi motoris tubuh yang tepat. Reaksi tubuh terjadi berdasarkan pada pengalaman sensoris dari reseptor-reseptor tersebut. Sedangkan reaksi sistem motoris tubuh dilakukan dengan mengatur kontraksi otot rangka, otot organ internal tubuh serta fungsi kelenjar tubuh. Misalnya kulit lengan menyentuh bahan panas, rangsangan dari luar tersebut diterima reseptor syaraf, dialirkan oleh sistem sensoris tubuh ke susunan syaraf pusat untuk diolah, hasil olahan tersebut dikirim ke sistem motoris tubuh untuk menentukan reaksi tubuh yang perlu diambil. Dua komponen penting yang berperanan dalam proses kerja sistem syaraf tersebut adalah sel syaraf (neuron) dan sambungan antar syaraf (sinapsis).

\subsection{Definisi Jaringan Syaraf Tiruan}

JST menurut Kohonen, didefinisikan sebagai sebagai suatu jaringan terhubung paralel yang biasanya terdiri dari elemen-elemen adaptif dan terorganisasi hirarkinya, yang diharapkan dapat berinteraksi dengan benda atau keadaan nyata sama seperti sistem syaraf otak biologis melakukannya. JST juga dapat dipandang sebagai suatu sistem yang terdiri dari elemen-elemen pengolah terdistribusi secara paralel dengan kemampuan untuk memperbaiki kinerjanya melalui proses belajar.

Dari definisi di atas secara umum suatu JST terdiri dari elemen-elemen pengolah (processing elements atau neurons), disusun membentuk suatu struktur jaringan tertentu, dan berusaha meniru sistem syaraf biologis.

Suatu JST biasanya tersusun dari banyak lapisan neuron. Satu lapisan mengandung neuronneuron yang tersusun paralel. Neuron-neuron ini dapat saling tersambung atau tidak, bergantung pada struktur jaringan yang dipilih. Jika JST tersebut memiliki banyak lapisan maka neuron-neuron dalam satu lapisan tersambung dengan neuron-neuron pada lapisan yang lain. Lapisan yang berada antara lapisan input dan lapisan output disebut lapisan hidden.

Sambungan-sambungan tersebut diberi harga yang dapat diatur dan menyatakan kekuatan sambungannya, disebut pembobot jaringan (weights). Proses untuk mendapatkan harga pembobot yang diinginkan ini disebut belajar (learning) dan dikerjakan menurut algoritma belajar tertentu. 


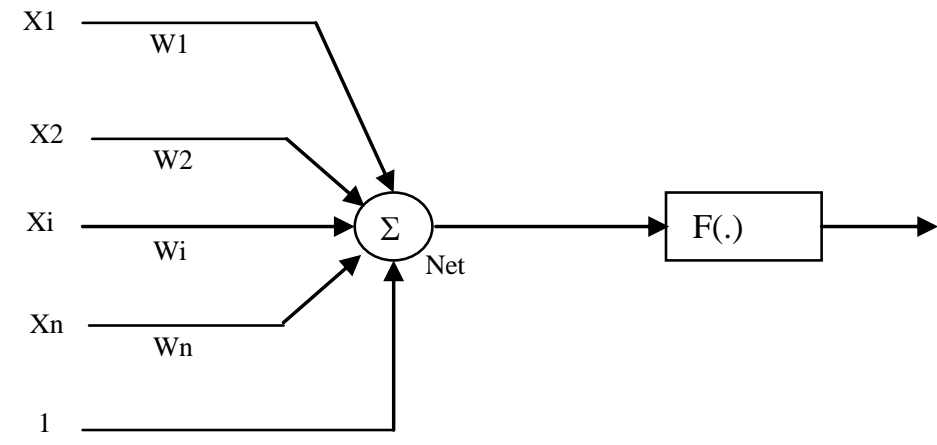

Input Output

Gambar 3. Elemen Pengolah Informasi (Neuron)

Gambar 3 menunjukkan neuron suatu jaringan syaraf. Input suatu neuron dapat berupa data dari luar jaringan atau merupakan output dari neuron yang lain.

Suatu neuron dapat terdiri dari pembobot penjumlah, fungsi keluaran serta dapat memakai elemen bias yang mempunyai harga input tetap biasanya 1.

\section{ANALISA DAN SIMULASI}

\subsection{Algoritma Klasifikasi Gangguan}

Sinyal gangguan hasil simulasi komputer di-DFT-kan untuk mendapatkan nilai dalam daerah frekuensi dan dicari kerapatannya dengan power spectrum density, kemudian dinormalisasi untuk mendapatkan nilai antara 0 sampai 1 sebelum digunakan untuk perhitungan komputasi dengan JSTKohonen yang akan mengklasifikasikan jenis gangguan.

Hal ini dapat digambarkan dengan diagram blok sebagai berikut :

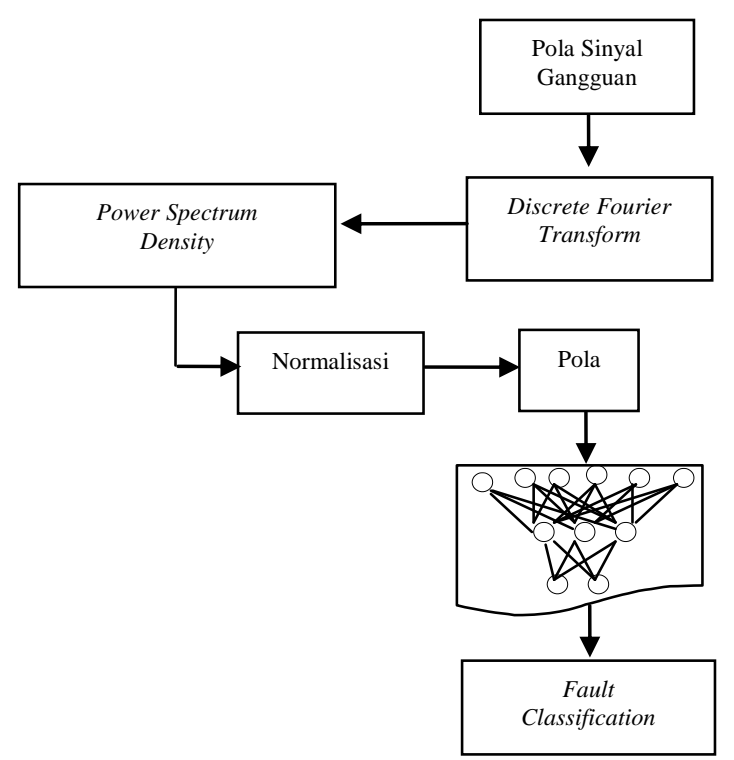

Gambar 4. Diagram Blok Klasifikasi 


\subsection{Pemodelan Sistem Tenaga Listrik}

Untuk menghasilkan sinyal gangguan dari hasil simulasi komputer, digunakan data dari IEEE dan dibuat simulasinya pada simulink Matlab.

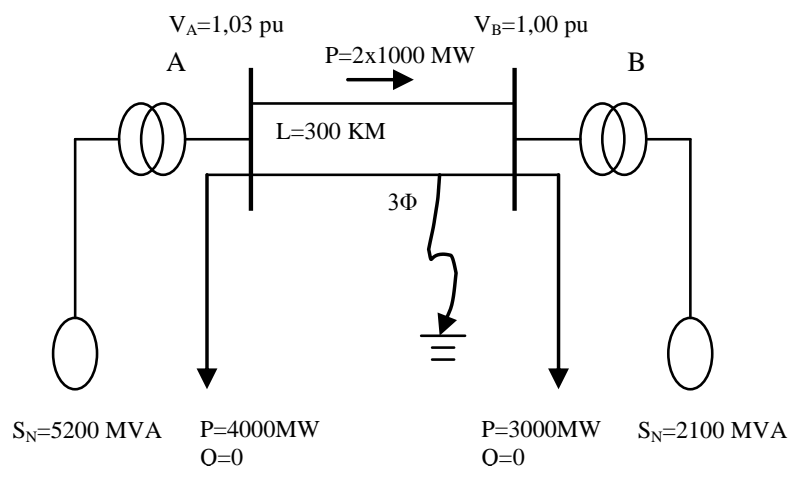

Gambar 5. Diagram Segaris Test $500 \mathrm{KV}^{1}$

Tabel 1 Data Sistem Transmisi 500 KV

\begin{tabular}{|c|c|c|}
\hline Data Generator & $\mathrm{A}$ & $\mathrm{B}$ \\
\hline $\mathrm{S}_{\mathrm{N}}$ & $5200 \mathrm{MVA}$ & $2100 \mathrm{MVA}$ \\
\hline $\mathrm{H}$ & $4.0 \mathrm{~s}$ & $4.0 \mathrm{~s}$ \\
\hline $\mathrm{Xd}$ & $1.00 \mathrm{pu}$ & $2.00 \mathrm{pu}$ \\
\hline $\mathrm{Xd}$ ' & $0.30 \mathrm{pu}$ & $0.25 \mathrm{pu}$ \\
\hline $\mathrm{Xd} "$ & $0.20 \mathrm{pu}$ & $0.20 \mathrm{pu}$ \\
\hline $\mathrm{Xq}$ & $0.60 \mathrm{pu}$ & $0.50 \mathrm{pu}$ \\
\hline $\mathrm{Xq} "$ & $0.20 \mathrm{pu}$ & $0.20 \mathrm{pu}$ \\
\hline $\mathrm{Xa}$ & $0.12 \mathrm{pu}$ & $0.15 \mathrm{pu}$ \\
\hline Tdo' & $5.00 \mathrm{~s}$ & $6.00 \mathrm{~s}$ \\
\hline Tdo" & $0.08 \mathrm{~s}$ & $0.03 \mathrm{~s}$ \\
\hline Tqo & - & $0.60 \mathrm{~s}$ \\
\hline Tqo" & $0.12 \mathrm{~s}$ & $0.06 \mathrm{~s}$ \\
\hline Excitation & Standard & Standard \\
\hline Prime mover & Turbine & Constant \\
& regulator & torque \\
\hline Transformer rating & $5200 \mathrm{MVA}$ & $2100 \mathrm{MVA}$ \\
\hline Reactance & $0.15 \mathrm{pu}$ & $0.15 \mathrm{pu}$ \\
\hline Local load & $3000+\mathrm{j} 0 \mathrm{MVA}$ & $4000+\mathrm{j} 0$ \\
& & MVA \\
\hline Load/Voltage & Proportional & Proportional \\
\hline Bus Voltage & $1.03 \mathrm{pu}$ & $1.00 \mathrm{pu}$ \\
\hline
\end{tabular}

Tabel 2 Data Sistem Transmisi 500 KV

\begin{tabular}{|l|l|}
\hline $\mathrm{r}$ & $0,018 \mathrm{Ohm} / \mathrm{Km}$ \\
\hline $\mathrm{x}$ & $0,34 \mathrm{Ohm} / \mathrm{Km}$ \\
\hline $\mathrm{b}$ & $4.9 \mathrm{e}-6 \mathrm{~S} / \mathrm{Km}$ \\
\hline $\mathrm{l}$ & $300 \mathrm{Km}$ \\
\hline $\mathrm{f}$ & $60 \mathrm{~Hz}$ \\
\hline
\end{tabular}

${ }^{1}$ ABB Power System AB,"Power Oscillation Damping Using Controlled Reactive Power Compensation a Comparison Between Series snd Shunt Approaches", IEEE Trans On Power System, Vol. 8 No.2, May 1993, FRG 


\subsection{SinyalGangguan}

Dalam membuat simulasi sinyal gangguan diasumsikan bahwa gangguan hubung singkat terjadi pada fasa-fasa sebagai berikut :

Satu fasa ke tanah terjadi pada fasa $\mathrm{C}$.

Dua fasa ke tanah terjadi pada fasa B dan C.

Tiga fasa ke tanah terjadi pada fasa A, B dan C.

Antar fasa terjadi pada fasa B dan C.

Tiga fasa terjadi pada fasa A, B dan C.

Pada gangguan satu fasa ketanah sinyal gangguan yang dihasilkan dari simulasi adalah :
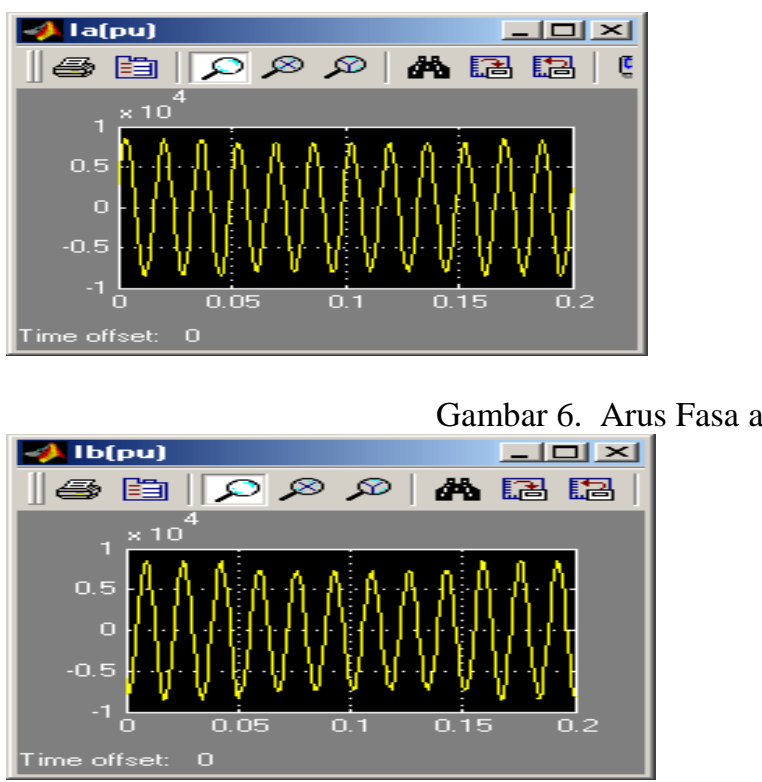

Gambar 7. Arus Fasa b

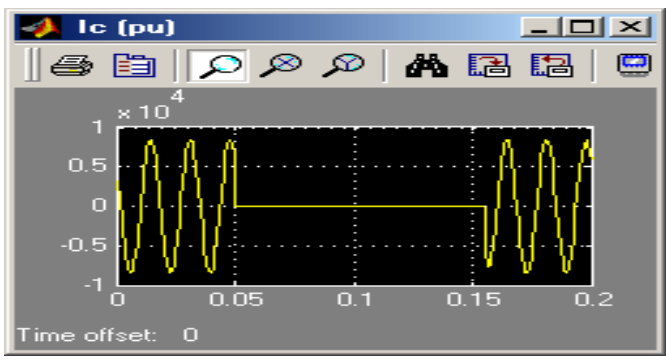

Gambar 8. Arus Fasa c

\subsection{Power Spectrum}

Untuk mendapatkan nilai data yang akan etraining pada JST-Kohonen, pola sinyal gangguan yang didapat dari simulasi kemudian dicari nilai power spectrum-nya menggunakan Discrete Fourier Transform (DFT). Power spectrum ini dicari dengan simulasi program komputer menggunakan Matlab. Sampling data yang diambil dari FFT sebanyak 64 data yang diambil pada saat terjadi gangguan. Dari power spectrum ${ }^{2}$ kemudian data akan dinormalisasikan nilainya dari 0 sampai 1 , sesuai dengan fungsi pemampat yang digunakan yaitu Sigmoid.

Fungsi sigmoid :

$$
f(x)=\frac{1}{\left(1+\exp ^{-x}\right)}
$$

\footnotetext{
${ }^{2}$ Welch P.D "The use of Fast Fourier Transform for the estimation of Power Spectra : A Method Based on Time Averaging Over short, Modified Periodegrams,"IEEE Trans. Audio Electroacoust, Vol.AU-15 (June 1967) PGS 70-73
} 
Untuk pelatihan sampling data akan dilakukan pada beberapa sampling waktu. Contoh DFT untuk sinyal arus pada gangguan satu fasa ke tanah.
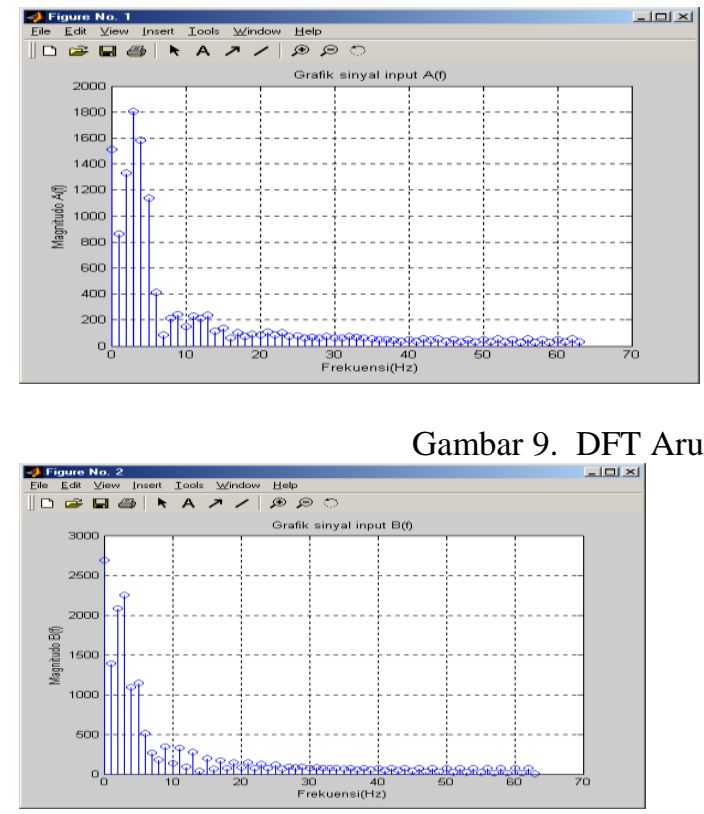

Gambar 10. DFT Arus Fasa a

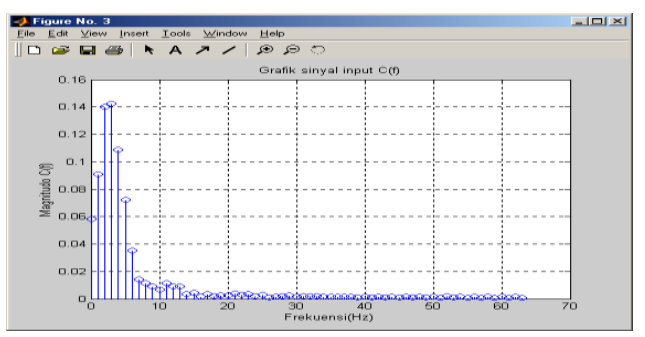

Gambar 11. DFT Arus Fasa b

\subsection{Simulasi JST-Kohonen}

Algoritma pembelajaran yang digunakan adalah Unsupervised, dimana output tidak ditentukan terlebih dahulu.

Pembobot awal ditentukan kemudian dihitung jarak terdekat dari masing-masing vektor unit hingga didapat nilai konvergensi yang mendekati atau sama dengan 1.

Pembobot awal sebagai inisialisasi adalah :

Tabel 3 Pembobot Awal

\begin{tabular}{|l|l|l|l|l|l|l|}
\hline \multicolumn{1}{|c|}{ Jenis Gangguan } & & 1 & 2 & 3 & 4 & 5 \\
\hline 1. Satu fasa ketanah & 1 & 0.3 & 0.5 & 0.7 & 0.2 & 0.1 \\
\hline 2. Dua fasa ketanah & 2 & 0.6 & 0.7 & 0.5 & 0.9 & 0.1 \\
\hline 3. Tiga fasa ketanah & 3 & 0.1 & 0.3 & 0.2 & 0.1 & 0.2 \\
\hline 4. Antar fasa & 4 & 0.2 & 0.1 & 0.1 & 0.3 & 0.2 \\
\hline 5. Tiga fasa & 5 & 0.9 & 0.1 & 0.7 & 0.3 & 0.4 \\
\hline
\end{tabular}




\subsubsection{Input JST}

Input dari JST-Kohonen adalah hasil dari normalisasi sinyal gangguan yang sudah di-DFTkan dan diambil nilai magnitude-nya.

Parameter input :

1. Sinyal arus pada fasa a.

2. Sinyal arus pada fasa $b$.

3. Sinyal arus pada fasa c.

4. Sinyal tegangan pada fasa a.

5. Sinyal tegangan pada fasa $b$.

6. Sinyal tegangan pada fasa a.

7. Sinyal tegangan antara fasa $a$ dan fasa $b$.

8. Sinyal tegangan antara fasa $\mathrm{b}$ dan fasa $\mathrm{c}$.

9. Sinyal tegangan antara fasa $\mathrm{c}$ dan fasa $\mathrm{a}$.

Dalam tiap parameter sampling data yang diambil sebanyak 64 data.

\subsubsection{Output JST}

Output JST adalah 5 macam gangguan yang akan diklasifikasikan dan pengkodean untuk gangguan yang akan diklasifikasikan adalah sebagai berikut :

Tabel 4.3 Kode gangguan

\begin{tabular}{|lccccc|}
\hline Jenis gangguan & \multicolumn{5}{c|}{ Pengkodean } \\
\hline Satu fasa ke tanah & $\mathrm{x}$ & $\mathrm{x}$ & $\mathrm{x}$ & $\mathrm{x}$ & $\mathrm{x}$ \\
Dua fasa ke tanah & $\mathrm{x}$ & $\mathrm{x}$ & $\mathrm{x}$ & $\mathrm{x}$ & $\mathrm{x}$ \\
Tiga fasa ke tanah & $\mathrm{x}$ & $\mathrm{x}$ & $\mathrm{x}$ & $\mathrm{x}$ & $\mathrm{x}$ \\
Antar fasa & $\mathrm{x}$ & $\mathrm{x}$ & $\mathrm{x}$ & $\mathrm{x}$ & $\mathrm{x}$ \\
Tiga fasa & $\mathrm{x}$ & $\mathrm{x}$ & $\mathrm{x}$ & $\mathrm{x}$ & $\mathrm{x}$ \\
\hline
\end{tabular}

Dengan metode pembelajaran yang unsupervised, maka dalam hasil output akan konvergen dalam letak yang tidak ditentukan, sehingga dalam tiap jenis gangguan akan muncul satu posisi matrik yang nilainya konvergen mendekati atau sama dengan 1, sehingga secara keseluruhan terdapat 5 posisi yang konvergen yang dapat digunakan untuk menentukan jenis gangguan.

\subsubsection{Training}

Untuk training dilakukan dengan pembobot awal dan untuk mempercepat informasi diberi koefisien learning rate 0.6 . Untuk mendapatkan pola hidden layer/kohonen layer yang paling tepat dilakukan training dengan mengubah-ubah pola hidden-nya. Perubahan pola hidden dapat dilakukan dengan mengubah-ubah pembobot awal dan menentukan iterasi yang sesuai.

\subsubsection{Hasil Training}

Hasil dari simulasi JST-Kohonen adalah mencari nilai konvergensi yang tepat/cukup memuaskan untuk digunakan mengklasifikasikan jenis gangguan, dan hasil simulasinya adalah sebagai berikut :

Tabel 4 Hasil Simulasi JST-Kohonen Untuk Klasifikasi Jenis Gangguan Iterasi 1

\begin{tabular}{|l|c|l|c|c|c|c|}
\hline \multicolumn{1}{|c|}{ Jenis Gangguan } & & \multicolumn{1}{c|}{1} & \multicolumn{1}{c|}{2} & \multicolumn{1}{c|}{ ( } & \multicolumn{1}{c|}{} & 5 \\
\hline 1. Satu fasa ketanah & 1 & 0.05422 & 0.5 & 0.94293 & 0.2 & 0.0064 \\
\hline 2. Dua fasa ketanah & 2 & 0.10445 & 0.7 & 0.93764 & 0.9 & 0.050984 \\
\hline 3. Tiga fasa ketanah & 3 & 0.09566 & 0.3 & 0.91285 & 0.1 & 0.059213 \\
\hline 4. Antar fasa & 4 & 0.0326 & 0.1 & 0.97696 & 0.3 & 0.0128 \\
\hline 5. Tiga fasa & 5 & 0.984 & 0.1 & 0.91136 & 0.3 & 0.067005
\end{tabular}


Tabel 5 Hasil Simulasi JST-Kohonen Untuk Klasifikasi Jenis Gangguan Iterasi 10

\begin{tabular}{|l|c|c|c|c|c|c|}
\hline \multicolumn{1}{|c|}{ Jenis Gangguan } & & 1 & 2 & 3 & 4 & 5 \\
\hline 1. Satu fasa ketanah & 1 & 0.02279 & 0.25536 & 0.9924 & 0.33969 & 0.001669 \\
\hline 2. Dua fasa ketanah & 2 & 0.03582 & 0.58458 & 0.99169 & 0.69631 & 0.01334 \\
\hline 3. Tiga fasa ketanah & 3 & 0.13393 & 0.38577 & 0.87368 & 0.29425 & 0.016336 \\
\hline 4. Antar fasa & 4 & 0.00890 & 0.05107 & 0.99693 & 0.6425 & 0.003339 \\
\hline 5. Tiga fasa & 5 & 0.99583 & 0.2621 & 0.94328 & 0.26614 & 0.017477
\end{tabular}

Tabel 6 Hasil Simulasi JST-Kohonen Untuk Klasifikasi Jenis Gangguan Iterasi 100

\begin{tabular}{|l|c|c|c|c|c|c|}
\hline \multicolumn{1}{|c|}{ Jenis Gangguan } & & 1 & 2 & 3 & 4 & 5 \\
\hline 1. Satu fasa ketanah & 1 & 0.02277 & 0.25506 & 0.99242 & 0.33986 & 0.001665 \\
\hline 2. Dua fasa ketanah & 2 & 0.035764 & 0.58444 & 0.99172 & 0.69606 & 0.013309 \\
\hline 3. Tiga fasa ketanah & 3 & 0.13399 & 0.38588 & 0.87357 & 0.29448 & 0.0163 \\
\hline 4. Antar fasa & 4 & 0.008889 & 0.051012 & 0.99694 & 0.64292 & 0.003331 \\
\hline 5. Tiga fasa & 5 & 0.99584 & 0.2623 & 0.94327 & 0.64292 & 0.017436 \\
\hline
\end{tabular}

Dari hasil perhitungan dengan menaikkan iterasi didapat satu posisi matrik untuk tiap jenis gangguan yang nilainya mendekati satu atau konvergen sehingga untuk klasifikasi gangguan hubung singkat dapat ditabelkan:

Tabel 4.8 Hasil Klasifikasi Gangguan Hubung Singkat

$$
\text { Jenis gangguan Pengkodean }
$$

1. Satu fasa ke tanah

2. Dua fasa ke tanah

3. Tiga fasa ke tanah

4. Antar fasa

5. Tiga fasa

$\begin{array}{lllll}\mathrm{x} & \mathrm{x} & 1 & \mathrm{x} & \mathrm{x} \\ \mathrm{x} & \mathrm{x} & 1 & \mathrm{x} & \mathrm{x} \\ \mathrm{x} & \mathrm{x} & 1 & \mathrm{x} & \mathrm{x} \\ \mathrm{x} & \mathrm{x} & 1 & \mathrm{x} & \mathrm{x} \\ 1 & \mathrm{x} & \mathrm{X} & \mathrm{X} & \mathrm{x}\end{array}$

\section{PENUTUP}

\subsection{Kesimpulan}

Dari hasil penelitian mengenai penggunaan jaringan syaraf tiruan (JST) Kohonen untuk klasifikasi gangguan hubung singkat pada saluran transmisi dapat diambil kesimpulan sebagai berikut : Pertama kelebihan metode Kohonen self organizing map terletak pada kemampuan belajar yang dimilikinya. Dengan tanpa adanya setting output, tetapi metode ini akan menghasilkan target yang diharapkan.

Kedua matrik yang didapat dari proses pembelajaran dapat digunakan untuk membedakan atau mengklasifikasikan jenis gangguan :

- Posisi matrik $(1,3)$ dengan pembobot 0.99242 mendefinisikan gangguan satu fasa ketanah.

- Posisi matrik $(2,3)$ dengan pembobot 0.99172 mendefinisikan gangguan dua fasa ketanah.

- Posisi matrik $(3,3)$ dengan pembobot 0.87357 mendefinisikan gangguan tiga fasa ketanah.

- Posisi matrik $(4,3)$ dengan pembobot 0.99694 mendefinisikan gangguan antar fasa.

- Posisi matrik $(5,1)$ dengan pembobot 0.99584 mendefinisikan gangguan tiga fasa. 
1. Metode Kohonen mampu menjelaskan kinerja otak yang mendekati kenyataan untuk mengenali input yang diterimanya kemudian menterjemahkannya pada output.

2. Sinyal input gangguan hubung singkat yang berupa sinyal analog harus diubah ke sinyal digital dengan disampling selama periode gangguan kemudian di-DFT-kan untuk mendapatkan sinyal dalam daerah frekuensi. Hal ini sangat penting untuk membedakan sinyal dengan frekuensi yang berbeda-beda.

3. Sistem yang digunakan adalah data dari IEEE yang disimulasikan dengan komputer, pada aplikasi selanjutnya metode ini dapat diterapkan untuk berbagai sistem.

4. Kemampun metode JST-Kohonen dalam mengklasifikasikan gangguan hubung singkat lebih cepat, dengan mendapatkan pembobot awal yang tepat maka iterasi dapat diperkecil.

\subsection{Saran}

1. Untuk aplikasi selanjutnya, metode ini dapat digunakan pada sistem tenaga listrik yang sesungguhnya.

2. Gangguan hubung singkat yang diklasifikasikan adalah gangguan hubung singkat yang terjadi pada satu titik, untuk gangguan yang bersifat simultan tidak dapat diklasifikasikan karena membutuhkan 1 perangkat jaringan syaraf tiruan lagi.

\section{DAFTAR PUSTAKA}

ABB Power System AB,"Power Oscillation Damping Using Controlled Reactive Power Compensation a Comparison Between Series And Shunt Approaches", IEEE Trans. On Power System, Vol.8, No.2, May, 1993.

Fukuyama, Yoshikazu; Ueki, Yoshiteru; "Fault Analysis System Using Neural Networks and Artificial Intelligence", IEEE Transaction on Power Delivery, 1993.

Howard Demuth, Mark Beale, "Neural Network Toolbox for Use With Matlab", The Math Work Inc., 1994.

H.P. Mauridhi, T.Ninik,"Penggunaan Metode Neural Network Untuk Klasifikasi Gangguan Pada Saluran Transmisi”,'Tugas Akhir, ITS, 2000.

John J. Grainger, William D. Stevenson, JR,"Power System Analysis", Mc-Graw Hill, Inc., International Editions, 1994.

Kohonen, Teuvo: "Self Organizing and Associative Memory", Springer-Verlay, Berlin Heidelberg, 1989.

Laurence Fausett, "Fundamental Of Neural Network Architectures, Algorithms And Application”, Prentice Hal, Englewood Clifs, New Jersey, 1994.

Reid, Cristopher; Passin, Thomas; "Signal Processing in C", Wiley and Sons inc, 1992.

Sandi S, "Artificial Intellegence", Andi offset, Yogyakarta, 1993.

Welch P.D,"The Use of Fast Fourier Transform for the Estimation of Power Spectra: A Method Base on Time Averaging Over Short Modified Periodegrams", IEEE Trans. Audio Electroacoust, Vol. AU-15 (June 1967) PGS 70-73. 